\title{
METALEPTIC REWRITING AS SHAM AUTHORIAL JUSTICE IN FLANN O'BRIEN'S AT SWIM-TWO-BIRDS
}

\begin{abstract}
In Flann O'Brien's At Swim-Two-Birds, a postmodernist novel avant la lettre, literary entities rewrite literary texts, including those in which they exist and I argue that they do so through metaleptic rewriting and in pursuit of different types of authorial justice, all of which are infelicitous. The novel's intense self-reflexivity and intricate metafictional games create a foundation that is too fluid to sustain the weight of a heavy concept such as justice. Thus, myriad fictional worlds filled with authors wishing to impose what they deem to be fair in their own literary universe interact, intersect and overlap, allowing their justice-motivated characters to metaleptically transgress their ontological levels in order to undo the wrongs of their authors. Yet, in a novel that promotes itself as 'a self-evident sham', such attempts are mocked at every step and the quest for fairness is replaced by the thirst for authorial power.
\end{abstract}

Keywords: Flann O'Brien; At Swim-Two-Birds; metalepsis; rewriting; justice; author.

When it comes to witty, entangled stories that refuse to obey the traditional norms of narrative construction, Flann O'Brien's At Swim-Two-Birds (1939) is one that is sure to induce what Robert Scholes called "moments of critical vertigo" (21), as it insatiably plays with ontological boundaries and makes a point out of dissolving them. The novel has been widely recognized as a most complex verbal labyrinth (Borges), an anatomy of the novel, and thus of itself (Cohen), a PlayText (Bohman-Kalaja), and even "the quintessential novel of violent metalepsis" (Malina 11). In its narcissistic engagement with literature, the text turns the mirror towards itself and displays a keen interest with regard to the process of (re)writing and its justification, as well as the nature and legitimacy of authorial justice.

The mise en abyme structure of At Swim-Two-Birds offers an opportunity to

\footnotetext{
* University of Bucharest; Romania.
} 
investigate the manner in which the creation of fluid worlds within worlds, of authors who are characters and characters who are authors may be used to analyze the nature of fictional writing and whether it is possible for authors to renounce their oppressive grip on their artistic creation and give freedom and justice to their characters. Although Flann O'Brien's novel literally and literary puts the author on trial, there has been little critical discussion of the implications of tackling concepts such as justice in this inherently ludic work that will not take itself seriously. Thus, I set out to examine how the multiple authors of At SwimTwo-Birds make use of metalepsis, in the Genettian, narratological understanding of this rhetorical term as the transgression of the "shifting but sacred frontier between two worlds: the world in which one tells, the world of which one tells" (Genette 236). This allows the character-authors to jump from one ontological level to another and rewrite their own realities in an attempt to bring about justice for themselves and others. In addition, I am interested in revealing how such a serious task is treated as a sham and how it subverts the aesthetic principles advanced by the novel within its own narrative.

Although no summary - not even the ones given by $\mathrm{O}^{\prime}$ Brien within the novel - may do justice to the manifold fictional realities that At Swim-Two-Birds brings into existence, it is important to delineate what I take to be its main ontological levels (see Figure 1). The irony of offering a structural model for a novel that escapes structurality is not lost on me, but the necessity for critical coherence and clarity in narratological analysis requires it. In the great chain of authors put forth in and by the text, it is perhaps appropriate to start with the historical, flesh-and-blood author, Brian $\mathrm{O}^{\prime}$ Nolan, who adopts the pseudonym Flann O'Brien for the authorial persona behind At Swim-Two-Birds. These two levels have been numbered 0 and 1 and because they are extratextual (historical, flesh-and-blood) and extradiegetic (fictive, yet outside the diegesis), respectively, they remain separate from the plot and untouched by the metaleptic contamination that affects the other levels.

The diegetic realm (level 2) presents an unnamed student who spends most of his time in bed, writing a metafictional and highly intertextual novel which he regulates in accordance with his academic interests, his biographical reminiscences and his friend's Brinsley's advice. This novel's main (and suspiciously absent) character is an author called Dermot Trellis (hypodiegetic level 3), who writes a book about sin, giving rise to a fourth level (hypohypodiegetic level 4) in which his characters live their life in - but mostly out of - 
Trellis's manuscript. Last, but not least, some of these characters, led by Trellis's son Orlick, decide to write a novel themselves (hypo-hypo-hypodiegetic level 5) in which the main character is their own author, Trellis.

This typology is based on Anne Clissman's famous division of the novel into four parts: "[w]e have then, three books in all: the narrator's book about Trellis, Trellis's book about sin, and Orlick Trellis's book about his father. If we add O'Brien's book about the narrator and his mind, we have four narratives, one within the other" (84-85). For the conceptualization of these embedded layers - in addition to which, I will also focus on the fifth one, which is the fictional result of Orlick's novelistic endeavor - I have used Marie-Laure Ryan's visual representation of Gerard Genette's narrative levels as a computer stack. I also align myself with Bohman-Kalaja's stance, according to which it is more accurate to consider these levels ontological rather than narrative and tackle them as worlds, not merely books, that generate a multiplicity of authorial voices ${ }^{16}$ and virtual texts. But, if for Bohman-Kalaja it is the different, characteristic types of games that distinguish between the levels, the present paper underlines the authorial need for justice through rewriting as the most important impetus behind the metaleptic transgression that prevents these levels from being rigid and fixed in their place.

From the very beginning of Flann O'Brien's novel, the unnamed studentnarrator appears to be a defender of freedom, since he intends to write a novel in which he does not abuse of his authorial power. To this end, he provides three different beginnings, a non-linear narrative, self-aware characters with seemingly independent minds, multiple and fluid narrative levels, a plethora of textual sources and styles of writing, and even multiple endings. In this respect, he anticipates the creed that the narrative voice of John Fowles's The French Lieutenant's Woman will express thirty years later: "we are no longer the gods of the Victorian image, omniscient and decreeing; but in the new theological image, with freedom our first principle, not authority" (Fowles 82). In order to be as explicit as possible in his democratic literary pursuit, the student offers his readers an aesthetic theory that may be taken as a model not just for the manuscript that he writes, but for the one in which he exists as well. ${ }^{17}$

\footnotetext{
${ }^{16}$ Bohman-Kalaja maintains that there are, in fact, twelve different narrators throughout At SwimTwo-Birds, each with their own story to tell (52).

17 If At Swim-Two-Birds is interpreted as a self-begetting novel, then the novel that the student writes is the same one in which he exists.
} 
The novel, in the hands of an unscrupulous writer, could be despotic. In reply to an inquiry, it was explained that a satisfactory novel should be a self-evident sham to which the reader could regulate at will the degree of his credulity. It was undemocratic to compel characters to be uniformly good or bad or poor or rich. Each should be allowed a private life, self-determination and a decent standard of living. This would make for self-respect, contentment and better service. It would be incorrect to say that it would lead to chaos. Characters should be interchangeable as between one book and another. The entire corpus of existing literature should be regarded as a limbo from which discerning authors could draw their characters as required, creating only when they failed to find a suitable existing puppet. The modern novel should be largely a work of reference." ( $\mathrm{O}^{\prime}$ Brien 25; emphasis mine)

Despite his overt aspiration to write a novel that would ensure a just, mindful and respectful attitude towards the characters, who should be allowed to live in a limbo, outside of the novels in which they perform their roles, the student subverts his own theory, allowing for paradox to lie at its heart. He champions freedom and social justice for characters, while also presenting the novel as "a self-evident sham". The narrator's socially-charged agenda of avoiding despotism and treating characters - who are, by nature, bound to their textuality and the decisions of their authors - as real human beings with their own rights is incompatible with the farcical, metafictional type of novel that takes every opportunity to flaunt its own artificiality "in defiance of verisimilitude" (Genette 236). Thus, although all of the main authors - whose existence stems from the embedded worlds encompassed by the one in level 2 in which the student writes - will, in one form or another, attempt to implement a justicebased system through the intrinsic freedom of metaleptic rewriting, these accounts are condemned to failure because they occur within the pages of a burlesque novel that rejoices in playing paradoxical games.

For the sake of demonstrating his own theory and illustrating the consequences of authoritarian authorship, the student creates the characterauthor Dermot Trellis, whom he sets up for failure by turning him into the exact model of unscrupulous, tyrannical author that should be rejected and dethroned because he forces characters to be either uniformly good or utterly evil. It is important to mention that Trellis wishes to write a realistic novel that would 
mirror the evils of the society in which he lived, so the premise from which he starts is one of purging the world of sin through exposing and then punishing the sinners in his fiction.

Trellis ... is writing a book on sin and the wages attaching thereto. He is a philosopher and a moralist. He is appalled by the spate of sexual and other crimes recorded in recent times in the newspapers - particularly in those published on Saturday night. . . . Trellis wants this salutary book to be read by all. He realizes that purely a moralizing tract would not reach the public. Therefore he is putting plenty of smut into his book. There will be no less than seven indecent assaults on young girls and any amount of bad language. There will be whisky and porter for further orders. ( $\mathrm{O}^{\prime}$ Brien 35; emphasis mine)

This intention alone does not does not make Trellis a tyrant, albeit the emphasis on justice does shed light upon his assumed moral superiority. ${ }^{18}$ The fact that the didactic fiction employed by Trellis is rooted in a morality understood through the lens of religion is a mirroring of the unnamed student's uncle, an authoritative figure who often accuses him of falling prey to the sin of sloth: "As you know yourself, I have strong views on the subject of idling. Lord save us, there is no cross in the world as heavy as the cross of sloth . . Idleness darkens the understanding; idleness weakens the will; idleness leaves you a very good mark for the sinful schemes of the gentleman down below." (327) Hence, it is easy for the student to imagine an author who would use his position of power to condemn others for their sinful behaviour.

The use of poetic justice seems to be representative of the traditional type of literature that the student disagrees with. Although the term was coined by Thomas Rymer in his seventeenth century work The Tragedies of the Last Age (1678) and was heavily employed by early novelists in England, the doctrine itself is much older than the novel. Rymer adapted it from René Rapin (who turned towards Aristotle ${ }^{19}$ for legitimacy) and discussed it in the context of

\footnotetext{
${ }^{18}$ Trellis's moral front is mocked by the student-narrator in the same breath in which it is asserted, through the fact that, under the pretense of reaching a mass audience, Trellis enjoys writing an indecent novel.

19 According to M.A. Quinlan, Aristotle was misinterpreted by Rymer, since the ancient philosopher's interest did not seem to lie in promoting justice, but in the emotions stirred by
} 
drama when, comparing history to literature, he saw in the latter an opportunity to express a universal ethical truth that might otherwise escape the sanction of society.

And, finding in History, the same end happen to the righteous and to the unjust, virtue often opprest, and wickedness on the Throne; they ${ }^{20}$ saw these particular yesterday-truths were imperfect and improper to illustrate the universal and eternal truths by them intended ... They concluded that a Poet must, of necessity see justice administered, if he intended to please. . . Poetry discover'd crimes, the Law could never find out; and punish'd those the Law had acquitted. (Rymer 22, 27)

Yet the conceptualization of literature as a means of doing justice and simultaneously offering a positive example to readers and a satisfactory fictional ending that would please them is at least as old as Plato, ${ }^{21}$ according to whom it was mandatory that poets abided by the principles of justice.

[Poets] are guilty of making the gravest mis-statements when they tell us that wicked men are often happy, and the good miserable' and that injustice is profitable when undetected, but that justice is a man's own loss and another's gain - these things we shall forbid them to utter, and command them to sing and say the opposite. (Plato 130)

What such examples prove is that the ethical requirement of punishing vice and rewarding virtue through poetic justice is one of the essential features of literature and the preoccupation with this aspect traditionally turned the author into a teacher whose duty was to instruct and direct his audience towards the greater good.

In similar vein, Trellis's novel is born out of a desire to bring justice into an

bringing good people from prosperity to adversity - this scenario should be avoided not on account of its injustice, but because it elicits neither pity, nor fear (53-4).

${ }^{20}$ In this passage Rymer is referring to Sophocles and Euripides.

${ }^{21}$ There is a similar assertion in Book II of Plato' Laws: "If I were a law-giver, I would try to make the poets and all citizens speak in this strain; and I would inflict the heaviest penalties on any one in all the land who should dare to say that there are bad men who lead pleasant lives" (qtd. in Quinlan 42). 
unjust world, but the manner in which the author goes about this moral ambition oh his seems to be, at least according to the rules set in place by the studentnarrator, profoundly immoral. To best suit the nature and purpose of his novel, Trellis requires characters that are flat and simplistic, but problems arise when he employs round characters whom he rewrites as one-sided. This results in a great disparity between the characters' true selves revealed through their independent personality and the roles that they are forced to play in Trellis's novel, "which [often] seems to be offensive to their own moral sense" (Cohen 221). The task of explaining this predicament falls onto the shoulders of the student-narrator since Trellis himself is asleep almost all throughout the novel - who reveals that most of Trellis's characters are not his own, but are, instead, independent characters who are picked from a limbo (adhering to the student's theory), 'hired', 'borrowed' or plainly taken, either from a fellow author called Mr. Tracy or from Irish mythology and then they are repurposed.

In rewriting their personalities and their stories, Trellis makes use of horizontal metalepsis (also known as intertextual metalepsis or heterometalepsis), ${ }^{22}$ which allows for the transgression to occur between two parallel worlds: for example, characters from different stories address one another or interact, as they migrate from one fictional text to another, "inhabit[ing] more than one storyworld or, to express it another way, mov[ing] from one ontological domain to another" (Bell and Alber 169). Indeed, Trellis's characters reflect this impossibility of communicating across ontological domains when they freely converse with other characters from a different novel by the same author, interact with others whom they have common past experiences with from other literary works, but perhaps most importantly, are themselves constantly rewritten with each story they appear in. Their metaleptic appropriation goes beyond mere intertextuality, ${ }^{23}$ since characters have memories of their previous texts and have a fully developed personality that may fall in line with or may be against the conditions of the literary world that they currently inhabit.

Even in the rare cases in which Trellis's characters are created by him, they are born through a process called 'aestho-autogamy', which means that they enter the fictional world as fully-developed adults, "with a memory but without

${ }^{22}$ Frank Wagner calls this transgression 'intertextual metalepsis', Sophie Rabau studies it under the name 'heterometalepsis' and John Pier mentions it as 'horizontal metalepsis of the enuncitate'. 
a personal experience to account for it" (O'Brien 9). This is the case of John Furriskey, whom the student portrays as one of Trellis's victims, since he is essentially a good character, but rewritten to be a "depraved character, whose task is to attack women and behave at all times in an indecent manner" (O'Brien 61). Even though Furriskey is not borrowed from another novel, he does seem to have a memory, a personality and a moral sense that are independent from what the author endows him with, which makes his role of "a man of unexampled depravity" (O'Brien 35), difficult to go along with. As if aware of this situation, his creator gives him the ability to metaletically step down from his level, be aware of his fictionality and even hear his author giving him orders through a voice that comes from a cloud. Through this transgression, Furriskey denies "the boundary separating the world(s) of the representation from the world(s) of the represented ... [which means that he] belongs (at least temporarily) to distinct spatiotemporal frames of reference, which results in a fiction-internal paradoxical transgression defying representational logic" (Haneback 25). Although author and character interact, the hierarchical relationship between them is clearly established, since Trellis invokes his unequivocal and ultimate authorial power through warning his character never to neglect or go against his mission, lest he should be severely punished.

At the conclusion of the interview, the voice administered a number of stern warnings as to the penalties which would befall him should he deviate, even in the secrecy of his own thought, from his mission of debauchery. His life was to be devoted without distraction to the attainment of his empirical lusts. (O'Brien 52)

This specific command entails that the author is aware of the possibility of his characters disobeying, so he finds it necessary to adopt a strict position to ensure that his rewriting is not reversed or tampered with. According to the student, it is not just Furriskey that has to be kept in check, but Trellis's control is overarching and absolute, affecting all of his characters. Indeed, as a true "representative of the despotic author class" (Cohen 221), he enforces his dominion by compelling his literary companions to live with him at the Red Swan Hotel, so he can always know what they are doing and lock them up in their 
rooms ${ }^{24}$ before he goes to bed $\left(\mathrm{O}^{\prime}\right.$ Brien 35$)$. This shift of worlds that the characters are subjected to as they are brought from level 4 to level 3 to is what Monika Fludernik calls "ontological metalepsis 2: lectorial" (389) and what Sonja Klimek takes to be 'descending metalepsis', which is the "phenomena of fictitious things or characters coming to life on the level that includes the representation of their own fictitious world" (170). Thus, Trellis is so focused on unmasking the injustice of the world around him, that he does not consider how his own rewriting enslaves the characters and not only reimagines them as flat, but imposes this nature onto them and maintains it through the close supervision and physical restriction that descending metalepsis arms him with.

Moreover, the moralistic author's hypocrisy and lack of moral legitimacy is further revealed through descending metalepsis, when he becomes intimate with one of the female characters that he has brought into and subsequently out of fiction. So attracted is he by the beautiful and refined Sheila Lamont that he assaults her himself, ${ }^{25}$ which results in the birth of his semi-literary son, Orlick Trellis. Considering that the manuscript was meant to rely extensively on the debasement of sexual encounters, it is ironic that the author engages in the same act that he seeks to denounce, while the villain of his story, Furriskey, does his best to avoid indecent behavior. At the risk of being caught, characters "arrange to lead virtuous lives, to simulate the immoral actions, thoughts and words which Trellis demands of them on pain of the severest penalties" (O'Brien 61) and manage to get the most out of their independence by drugging the author and having him fall asleep ${ }^{26}$ for long periods of time. The consequences of forcibly rewriting already written characters is most evident when their extranovelistic actions sharply diverge from their novelistic roles: instead of assaulting Peggy, Furriskey loves, respects and wishes to marry her, instead of performing only unimportant parts, Paul Shanahan draws attention to himself, becoming one of the main characters, as for Finn MacCool, despite being employed as a father-

\footnotetext{
${ }^{24}$ Multiple levels of this hotel seem to be dedicated to the stay of the characters: "There is a cowboy in Room 13 and Mr McCool, a hero of old Ireland, is on the floor above. The cellar is full of leprechauns" (O'Brien 35). Despite such specific details, the existence of the hotel itself is doubtful, since "Nobody knows whether they are there at all or whether it is all imagination" (O'Brien 99).

25 The attraction for his own creation may be considered a parody of the Pygmalion mtyh.

${ }^{26}$ This emphasis on sleep and the allure of spending time in bed on the part of the authors is emphasized all through the novel, showing how prone writers are to losing the control that they so adamantly seek: "Trellis's dominion over his characters, I explained, is impaired by his addiction to sleep. There is a moral in that." (O'Bien 99).
} 
figure on account of his venerable reputation as a mythical Irish giant of the Fenian cycle, he does not protect Peggy, but assaults her himself. However, the tighter Trellis's grip on his characters is and the more he insists on rewriting them against their will for the sake of power under the guise of justice, the more they seek ways to evade, trick and even rebel against him.

If thus far I have focused on the author's perspective, it is important to also consider what the characters feel when they are used, reused and misused by their authors, so as to establish a basis for their desire to regulate authorial justice. Since these literary entities understand that they are fictional, they are able to metaleptically transcend the world in which they are placed and reflect upon their condition. For instance, Finn denounces the manner in which himself and his fellow Irish character Sweeney, taken from the medieval legend The Frenzy of Sweeny have been used by authors.

Small wonder, said Finn, that Finn is without honour In the breast of a seablue book, Finn that is twisted and trampled and tortured for the weaving of a story-teller's book-web. Who but a book-poet would dishonour the God-big Finn for the sake of a gap-worded story? . . . Who could put a terrible madness on the head of Sweeney for the slaughter of a single Lentgaunt cleric; to make him live in treetops ... Who but a storyteller? Indeed, it is true that there has been ill-usage to the men of Erin from the bookpoets of the world and dishonour to Finn. (O'Brien 19-20)

It is the textual manipulation involved in the process of writing that bothers the characters and makes them feel disrespected. Although fictional, they expect distributive justice - that is to be treated with the same respect, dignity and equity that human beings deserve. While this may sound like a ridiculous claim, in a world in which author and characters coexist on the same ontological level, the grievance is not necessarily absurd - the only issue is that there is no possible solution out of their existential conundrum.

Albeit still created characters, Finn MacCool, Anthony Lamont and Paul Shanahan recognize the authority that their authors have and wish to emulate it by becoming storytellers themselves and experiencing what it is like to be a creator. Consequently, outside the borders of Trellis's text, but still in a limbo sustained by the student's writing, they become involved in a narrative competition at level 4 , aimed at finding out who is most capable of capturing the 
attention of other characters. In this metafictional game, the characters fulfil all the roles: they are authors, protagonists and listeners/readers. While Finn tries to tell the story of Sweeney, the two modern characters become bored and constantly interrupt him with their own versions, which are colloquial, spontaneous and based on their own previous literary experiences, reimagining the original story through its association with nationalist jumping contests and racy cow-puncher's adventures.

This competition combines horizonal and descending metalepsis, since characters interact with each other and their listeners in an unknown literary space that comprises stories and entities from multiple worlds, all the while being aware that they are fictitious, yet still able to take the reins of their stories. The public spectacle of establishing who has narrative control over whom is rooted, thus, in a "a paradoxical contamination between the world of the telling and the world of the told" (Pier 190) that makes it difficult to establish any narrative boundaries. Through entering the world of their representation, MacCool, Lamont and Shanahan wish to draw attention to an unjust imbalance of power between writer and character that paves the way towards abuse, yet the moment they gain control, they too re-envision and manipulate stories beyond recognition.

It is both the sense of having been wronged and the understanding that it is only authors who hold a position from which to bring about justice that generate the characters' arduous and very personal quest to change their status from being written to being the ones who do the writing, and thus "tak[e] hold of (telling) by changing level" (Genette 235) and disturbing narrative logic. Interestingly, instead of descending to the level of their author, they choose to write a new book, which adds another ontological level to the narrative stack through embedding (Ryan 204). In this world, they rewrite both themselves (moving from level 4 to level 5) and their author, Trellis (who jumps from level 3 directly to level 5) in an instance of ascending metalepsis, through which "things or characters from the level of representation introduce themselves on the level of what is represented" (Klimek 170).

Thus, the hybrid character Orlick, who seems to have inherited his father's talent for writing, is now the main author, guided by a sense of bringing justice to the memory of his mother. However, in order to avoid the mistakes of Trellis and the pitfalls of domineering, oppressive writing, the plan is to have multiple authors and write the novel in collaboration with John Furriskey, Anthony 
Lamont and Paul Shanahan, whose interest lies in a broader type of literary justice that centres around punishing the author by stripping him of his authorial power.

Greatly excited, they suggest that he utilize his gift to turn the tables (as it were) and compose a story on the subject of Trellis, a fitting punishment indeed for the usage he has given others. Smouldering with resentment at the stigma of his own bastardy, the dishonour and death of his mother, and incited by the subversive teachings of the Pooka, he [Orlick] agrees. (O'Brien 164; my emphasis)

The resulting transition from one level to another changes the nature of all those involved and is an attempt to rewrite not just Trellis's manuscript, but At SwimTwo-Birds itself, since it features almost all of the original characters, but with the balance tipped greatly in favour of the previously mistreated ones. As Orlcik himself proudly proclaims, it is a type of story "that combines justice with vengeance" ( $\mathrm{O}^{\prime}$ Brien 183). Consequently, Trellis is now the protagonist, for the sole purpose of being held accountable for his tyrannous behaviour, while Furriskey, Lamont and Shanahan, albeit apprehensive to become characters once again, trust Orlick to rewrite them in the best possible light: from uncultivated and lowbrow to admirable, highbrow, handsome gentlemen, "magnificent specimen[s] of manhood" (O'Brien 187), whose exaggerated characteristics make for humorous and dramatically ironic descriptions.

With Trellis's fate now lying in the hands of his creation, the main issue seems to be agreeing upon what type of punishment is most fitting, how it should be administered and thus, what kind of story it would be. The ensuing brainstorming, writing and rewriting are decisively geared towards torturing and eventually murdering Trellis, but while Orlick has aspirations of creating great literature based on suspense and psychological turmoil, the others just want quick, retribution through the infliction of bodily pain, ensuring they get the author before he gets them (172). The constant, eager interruptions on the part of the co-authors mirrors the previous narrative competition and reveals that the opinionated characters find it impossible to obey a single author and remain passive in the process of literary creation.

Hence, in this case too, while Orlick is temporarily absent, Lamont and Shanahan take charge of the novel. It is not only that they consider boils, varicose 
veins, burst eyeballs, needles, thorns and collapsed roofs not torturous enough, but they do not want to let Trellis rest while Orlick is not writing.

Gentlemen, said Shanahan, we're taking all the good out of it by giving him a rest, we' re letting him get his wind. Now that's a mistake. .

Now be careful, warned Lamont. Easy now. You'd better leave him be. We're doing very nicely so we are.

Not at all, man. Listen. A little party on our own. (O'Brien 181; emphasis mine)

The metaleptic premise is that while he is not tormented through fictional narrative writing, Trellis is given the possibility to rest - a concern that is reiterated after Orlick returns and the authors think of turning in and continuing the story the following day: "Do you think it would be safe to go to bed and leave him where he is to the morning? he asked. I do not, said Orlick, Safety first." (O'Brien n. p.). This metalepsis is rooted in simultaneity. Allowing the characters to continue their activities independently of their being written, while the narrator is otherwise engaged means crossing the boundary between narrating time and narrated time, which are paradoxically linked together through simultaneity. As Monika Fludernik asserts, "the extradiegetic narrator would have to be located in the story, otherwise the while cannot link the same kind of temporality" (387) In other words, Trellis could not rest, unless his narrators and him were in the same world (level 5). Although "Genette's notion of diegetic levels considers the world of which one tells as 'a re-counting' - [and] as such, it does not exist independently of the act of narration" (Haneback), this logicdefying crossing is no surprise for the characters of At Swim-Two-Birds, who generally encounter no obstacles in (literally) playing a cat and mouse game with their author while he is either/both asleep at level 3 and tortured at level 5.

With a brutal treatment that includes both legs broken, all ribs fractured, a whole in the head, a kick in the face and many other violent inflictions while Trellis "had no choice because orders is orders" (O'Brien 182) since characters do not have a say in their story, it is evident that the initial quest for justice has turned into a sham that rests upon the pursuit of low entertainment and black humor. Lamont and Shanahan in particular use this opportunity to quench their thirst for vengeance and turn Trellis into a character of absolute evil, a flat character with no complexity to him, that knows nothing but sinful and 
reprehensible behavior and, must thus be punished ad infinitum and supernaturally survive only to receive further punishment. Just like Trellis, they are so absorbed by their task that they assume absolute control and become the same type of unscrupulous author that they denounce.

In addition, the characters feel the need to rewrite their author as "a fugitive from Justice ... [who] should be tried and well tried" (O'Brien 193), that is, legally tried for his literary crimes. What follows is a plot which claims to aim at retributive justice (deciding upon appropriate sanctions), but seeks to attain it without procedural justice (which ensures that the trial itself is conducted fairly and objectively). In this sense, one of the most well-known theories that establishes the criteria necessary for procedural justice has been advanced by Tom Tyler.

Procedural justice, as the name implies, focuses on whether the procedures used to make an allocation determination are fair, without regard to the actual outcome. Tyler (1991) identifies four key factors that individuals weigh when determining whether a proceeding is procedurally fair: fairness and neutrality of the decision maker; opportunity to present one's side of the dispute (also called voice); trustworthiness (as opposed to mere neutrality) of the decision maker; and respectful treatment of all parties during the course of the proceedings. (Tomkins and Applequist 261)

But the new authors are too impatient, too personally involved and too firmly set on their verdict before the trial even begins, to offer Trellis a just legal representation. Nonetheless, they are concerned with appearances and so proceed with a courtroom story for the purpose of which they rewrite Trellis as the defendant and themselves, along with other fellow characters (Furriskey, Lamont, Shanahan, MacCool, Sweeney, Andrews, Willard, Casey, Kirsey, Tracy, Lamphall and Clohessy) as both judges and jury and sometimes even witnesses. Not only is such a story inherently metaleptic, since it presupposes that the authors and characters share the same ontological level, but it also plays so much with the conceptualizations of these two categories, that the frontier between their worlds can no longer stand. In brief, the previous-characters-now-authors judge the previous-author-now-character in their work for the crimes they remember he has committed in his work, which belongs to a lower-level and in which the situation was reversed. This means that levels 3, 4 and 5 have 
"collapse[d], as if of their own weight, into a single level", which "is a general pattern in postmodernist multilevel texts" (McHale 115) and that these levels are now a 'heterarchy' (McCulloch) because it is contains elements that are "unranked or ... possess the potential for being ranked in a number of different ways" (Crumley 3).

The elements that make a mockery out of this trial and shroud the pretense of justice in a farcical veil stem from a profound disregard towards procedural justice. The judges are all dressed in judicial robes, able to speak Latin and to employ legal terms, especially court vocabulary, but they are far from being neutral since they are personally involved and fulfil more than one role in the trial, which entails that their ability to suppress bias and prevent favoritism in impaired (Tyler 105). Trustworthiness is also undermined through the fact that they drink alcohol, play cards and, fall asleep instead of paying attention to the witnesses' testimonies and one of the judges even pickpockets his colleague. In terms of the respect due to all parties, the judges are more interested in defending the honor of those who take the stand, whom they treat with utmost politeness than letting Trellis finish his statements or provide him with medical help for the multiple injuries he is suffering from. The basic principle of audi alteram partem (hearing the other side) is also clearly breached, yet there seems to be an interest in maintaining the legal appearance: Trellis is offered a choice of lawyers, although both of them are mute, he is allowed to cross-examine the witnesses, although he is often interrupted and he does have a voice, although its volume is regulated by the authors.

At this stage, the prisoner, in order to protect his constitutional rights and also in an endeavour to save his life, pointed out that this exchange of pleasantries was most irregular and that the evidence of the witness was valueless, being on his own admission a matter of hearsay and opinion; but, unfortunately, as a result of his being unable to rise or, for that matter, to raise his voice above the level of a whisper, nobody in the court was aware that he had spoken at all .... ( $\mathrm{O}^{\prime}$ Brien 206)

In addition, the judges are unsure of the charges and are content to proceed based on the fact that the defendant "looks a very criminal type" (O'Brien 193), which is reinforced by the fact that all the metaleptic accusations brought by the witnesses (employer's negligence, inadequate payment, unsanitary working 
conditions, character assault and plagiarism, ${ }^{27}$ among others) are revealed spontaneously and without any evidence to support them. There is no ontological line drawn between how the witness-characters are treated while in the novels and how they are provided for outside of the same novels, a space in which their very existence and interaction with the author defies narratological logic through ontological metalepsis. Fundamentally these claims are fictitious and impossible to defend due to the absurdity of them being treated as real, despite the fact that they are rendered at the fifth level of representation and that "ontological metalepsis ... is incompatible with a realistic framework" (Ryan 210).

Since the judges have rewritten themselves as such, albeit having no true apprehension of the legal system and no interest in conducting an impartial trial, it is safe to say that it is merely the appearance of retributive justice that is important to them. This is overtly stressed by the characters and it comes with the admission that instead of receiving a jury of his peers, Trellis received a jury of his own making, which underlines the fact that the characters' rewriting is metaleptic and that they might have set themselves as king-judges on level 5, but they still belong to their original ontological level 4 .

You think the jury has heard enough evidence?

Certainly they have, said Shanahan. The time for talk is past. Finish the job tonight like a good man ...

He can't complain that he didn't get fair play, said Furriskey. He got a fair trial and a jury of his own manufacture. I think the time has come. . . . We will have one more witness for the sake of appearance, said Orlick, and then we will get down to business. (O'Bien 207-8)

The same understanding of their own metaleptic migration is also revealed when Orlick becomes fearful of the consequences of his actions: "As long as you realize the importance of the step that is about to be taken, said Orlick, I have no objection. I only hope that nothing will happen to us. I don't think the like of this has been done before, you know" (O'Brien 208). More specifically, they wonder

\footnotetext{
${ }^{27}$ It is ironic that Trellis is accused of plagiarism, when all the fictional authors of this novel rely on extensive borrowing, intertextuality and pastiche, rewriting each other's characters; the unnamed student narrator does not seem to have any ethical concerns about using other authors' texts and integrating them into his own manuscript.
} 
whether or not sentencing Trellis to death at level 5 would not also entail his death at level 3, and implicitly, the obliteration of the entire level 4 which accounts for their existence.

The failure of the judicial system to bring justice to Orlick, Furriskey, Lamont and Shanahan is stressed through the fact that the trial never reaches an ultimate decision. In fact, the whole sham is terminated through the authorial intervention of the student who introduces a fateful element at level 3 that rewrites the ending of the story by unwriting the characters' novel and their conceptualization of justice along with it.

Teresa, a servant employed at the Red Swan Hotel . . . revived the fire and made a good blaze by putting into it several sheets of writing which were littered here and there about the floor ... it happened that these same pages were those of the master's novel, the pages which made and sustained the existence of Furriskey and his true friends. Now they were blazing, curling and twisting ... taking flight as if to heaven through the chimney . . . (O’Brien 215-216)

Instead of letting the characters continue their novel, the student engages in a display of authorial power which is ironically assumed in order to defend his aesthetic theory about the freedom of characters and the importance of avoiding despotic novels. His act of preventing the new tyrannical authors from bringing their plan to fruition seems to be based on poetic justice, since the villains that plotted the death of the protagonist are punished and die themselves through a fictional turn of events that discovers those crimes that the law has missed. It is also metaleptic, because although the victim-character Trellis is not physically injured, he returns to his original level 3 only after Furriskey and the others have died. This happens because "[w]hen a story is completed, it is popped from the stack, and the narration returns to the preceding level" (Ryan 205). It is then that he finds himself confused, distressed and ill as a consequence of his crossing from one world to another.

However, the fact that it is Trellis - the embodiment of authorship itself that comes victorious out of the life and death game played with his characters brings doubts upon the legitimacy of the student's justice. How could this new judge be impartial, considering that he is himself an author and, thus inherently biased in his defense of authorship? While it is true that he does not agree with 
Trellis's fictional practice, the act of saving him may be based on a feeling of complicity (one author saving another) and the fear of creating a precedent. If this can happen to an author, who is to say that his characters would not, at some point, rebel against him? Thus, the student's authorial justice may be poetic, but it is arguable whether it is morally satisfying and just.

Flann O'Brien's At Swim-Two-Birds is not a novel, but multiple novels and novelistic theories into one. Considering the freedom of movement of the selfconscious and self-referential characters, the heterodiegetic narrative and the frequent metaleptic crossing of ontological boundaries that literary entities partake in, it would be easy to assume that its democratic principles permeate its textual world. However, dissatisfaction reigns amongst authors and characters alike and their impossibility to lead their existence at a single narrative level is rooted in a desire to pursue justice in and for the literary world. Yet, at different levels, the quest for fairness fails and it is replaced by the thirst for authorial power.

The first attempt is centred around Trellis, who seeks to bring about poetic justice founded upon a moral-religious system, but he does it through horizontal metalepsis by forcibly rewriting already written characters and flattening their personalities, but also descending metalepsis, since he enslaves them by bringing them to his world and locking them in his hotel. His authorial ambition of bringing justice through literature is most evidently subverted through the fact that he is himself immoral, hypocritical and tyrannical - which means that instead of purging the world of sin, he adds more sin to it.

A second type of justice is sought by the characters themselves who do everything in their power to undo the wrongs and abuses of authorship, which is ironic and, as it proves, impossible. In particular, they make use of ascending metalepsis to create a new novel in which they rewrite themselves and their author, casting everybody in different roles. This also proves to be infelicitous, since the moment that they find themselves in a position to control the narrative, they just want to entertain themselves, use elements of torture for their amusement and employ a legal context to hide the fact that their search for justice has turned into pure vengeance. Retributive justice is used as a mere mask behind which the characters employ unfair procedures to account for an alreadydecided verdict that only underlines how easily they can repeat the mistakes of the man they wish to condemn. In this case, metaleptic contamination affects all three top levels, making it impossibility to determine who is the author of whom 
and triggering the collapse of these levels into a single one, turning hierarchy into heterarchy.

The third, and final, attempt at justice comes from the student-narrator himself, who, under the guise of ridding his literary work of tyranny, rewrites its ending by unwriting the villains, which turns out to be an unjustified intervention that proves his bias rather than his fair judgment. It seems that, despite the theoretical insistence upon the necessity of creating literary worlds in which authors are not oppressive, all attempts at bringing about social justice to the characters are condemned to failure because the despotism of the author lies not in his person, but in the status of authorship itself. In this context, the justice that the characters chase so ardently can be nothing but "a self-evident sham" ( $\mathrm{O}^{\prime}$ Brien 25), a farcical exploration of fairness that is just as artificial as they are.

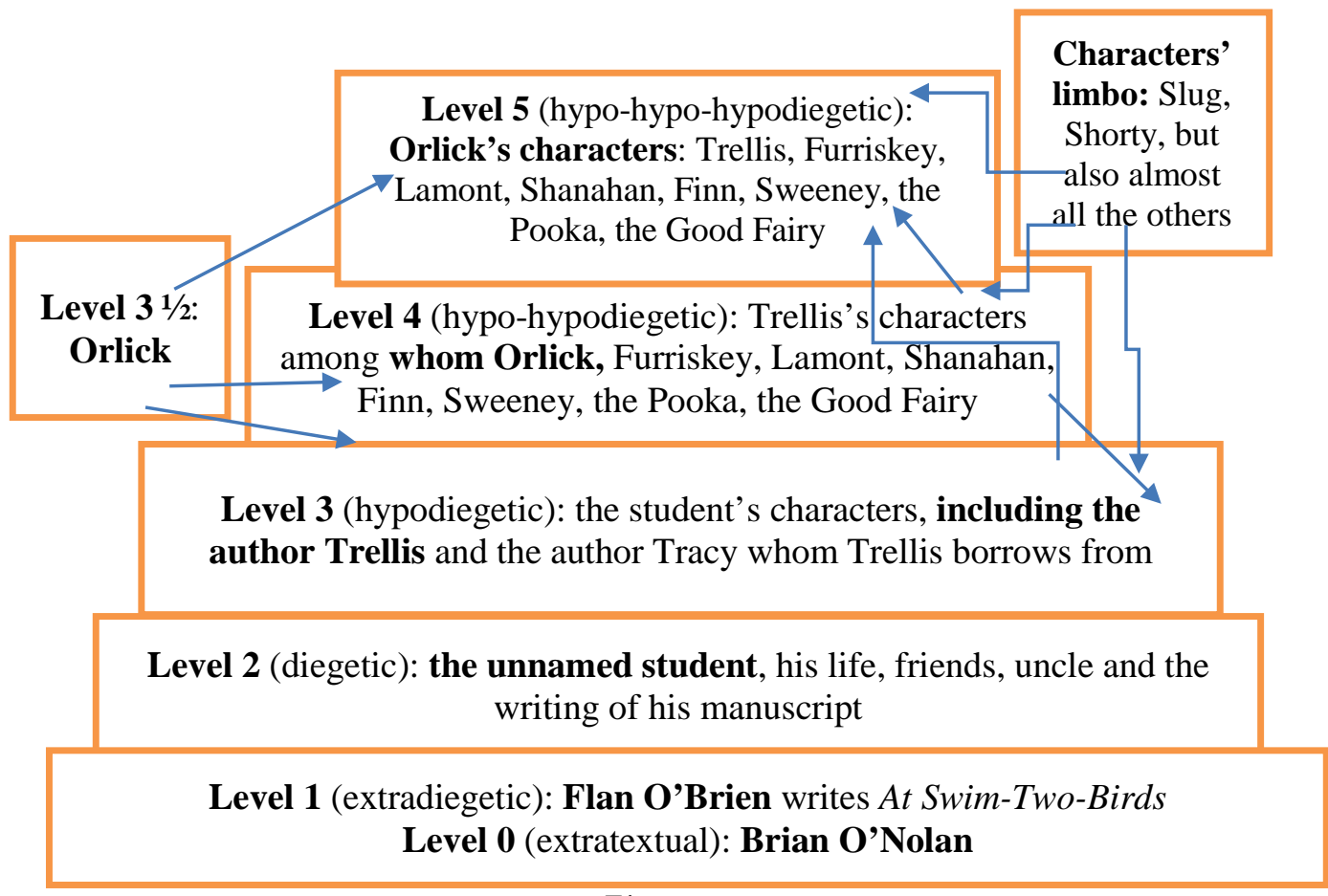

Figure 1.

\section{Works Cited}

Bohman-Kalaja, Kimberly. Reading Games: An Aesthetics of Play in Flann O'Brien, Samuel Beckett, \& Georges Perec. Dalkey Archive Press, 2007. Print. 
University of Bucharest Review $\propto$ Vol. XI/2021, no. 2 (new series)

Re-writing, Re-imagining the Past (IV)

Bell, Alice and Jan Alber. "Ontological metalepsis and unnatural narratology." Journal of Narrative Theory 42.2 (Summer 2012): 166-192. Print.

Borges, Jorge Luis. "When Fiction Lives in Fiction." 1939. Selected Non-Fictions. Ed. Eliot Weinberger. Trans. Esther Allen, Suzanne Jill Levine and Eliot Weinberger. New York: Penguin Books, 2000. Print.

Clissman, Anne. Flann O'Brien. A Critical Introduction to His Writings: The Storyteller's Book Web. Dublin: Gill \& Macmillan, 1975. Print.

Cohen, David. "An Atomy of the Novel: Flann O'Brien's At Swim-Two-Birds." Twentieth Century Literature 39.2 (Summer, 1993): 208-229. Print.

Crumley, Carole L. "Heterarchy and the Analysis of Complex Societies." Archeological Papers of the American Anthropological Association. 6.1 (January 1995): 1-5. Print.

Fludernick, Monika. "Scene Shift, Metalepsis, and the Metaleptic Mode." Style 37.4 (Winter 2003): 382-400. Print.

Fowles, John. The French Lieutenant's Woman. New York: Signet, 1969. Print.

Genette, Gerard. Narrative Discourse. An Essay in Method. Trans. Jane E. Lewin. Ithaca, New York: Cornell University Press, 1980. Print.

Haneback, Julian. Understanding Metalepsis: The Hermeneutics of Narrative Transgression. Berlin, Boston: Walter de Gruyter, 2017. Print.

Klimek, Sonja. "Metalepsis and Its (Anti-)Illusionist Effects in the Arts, Media and Role-Playing Games." Metareference across Media: Theory and Case Studies. Ed. Werner Wolf, Katharina Bantleon, Jeff Thoss. Brill, 2009. Print.

Malina, Debra. Breaking the Frame: Metalepsis and the Construction of the Subject. The Ohio State University Press, 2002. Print.

McCulloch, Warren. S. "A Heterarchy of Values Determined by the Topology of Nervous Nets." The Bulletin of Mathematical Biophysics 7 (1945): 89-93. Print.

McHale, Brian. Postmodernist Fiction. London and New York: Routledge, 1987. Print.

O'Brien, Flann. At Swim-Two-Birds. 1939. London: Penguin Books, 1967. Print.

Pier, John. "Metalepsis." Handbook of Narratology. Ed. Peter Huhn, John Pier, Wolf Schmid and Jörg Schönert. Berlin, New York: Walter de Gruyter, 2009. Print.

Plato. The Republic. Trans. Benjamin Jowett. Woodstock, Ontario: Devoted Publishing, 2017. Print.

Quinlan, M.A. Poetic Justice in the Drama: Dissertation. Leopold Classic Library, 2016. Print 
Rabau, Sophie. "Ulysse à côté d'Homère. Interprétation et transgression des frontières énonciatives." Métalepses. Entorses au pacte de la representation. Eds. John Pier and Jean-Marie Schaeffer. Ehess, 2005: 59-72. Print.

Ryan, Marie-Laure. Avatars of Story. Minneapolis, London: University of Minnesota Press, 2006. Print.

Rymer, Thomas. "The Tragedies of the Last Age." 1678. The Critical Works of Thomas Rymer. Ed. Curt A. Zimansky. New Haven: Yale University Press, 1956: 17-76. Print.

Scholes, Robert. "Metafiction." Metafiction. Ed. Mark Currie. London, New York: Routledge, 2013: 21-39. Print.

Tomkins, Alan J. and Kimberly Applequist. "Constructs of Justice: Beyond Civil Litigation." Civil Juries and Civil Justice. Psychological and Legal Perspectives. Ed. Brian H. Bornstein, Richard Wiener, Robert F. Schopp and Steven L. Willborn. New York: Springer, 2008: 257-72. Print.

Tyler, Tom R. "What is Procedural Justice?: Criteria used by Citizens to Assess the Fairness of Legal Procedures." Law \& Society Review 22.1 (1988): 103-136. Print.

Wagner, Frank. "Glissements et déphasages: note sur la métalepse narrative." Poétique 33.130 (2002): 235-53. Print. 